\title{
Some Circulation Data from a Research Library
}

This article contains the results of an analysis of the circulation for all monographs from a research library during a six-month period. The data have been tabulated and plotted to show the percentages of users accounting for the corresponding circulation.

$\mathbf{R}$ ECORDS WERE maintained during a sixmonth period of the names of the users and the number of books borrowed for all monographs circulating from the $\mathrm{AF}$ Cambridge research library. These data were then tabulated by user and ranked according to the number of monographs the user borrowed. The data were then grouped and tabulated as shown in Table 1.

The headings should be self-explanatory, but some comment will be made about the entries in order to avoid misinterpretation by the reader. Line 1 of Table 1 represents eight users who borrowed seventy or more books each, or a total of 827 monographs. These 827 monographs represented 9.2 per cent of the total circulation for the six-months study period, and the eight users represented .95 per cent of the users. Line 2 and the remaining lines of Table 1 represent cumulative data. For example, six people borrowed from sixty to sixtynine monographs each. This resulted in

Dr. Trueswell is Head of the Department of Industrial Engineering, School of Engieering, University of Massachusetts. This article was prepared as a part of the author's USAF active duty training through the Office of Aerospace Research with assignment at the AF Cambridge Research Laboratory Research Library. This data was provided through the cooperation of Ole V. Groos, Director of the AFCRL Research Library. a total of fourteen people (having the largest circulation needs) who borrowed sixty or more books each or a total of 1,217 monographs.

The cumulative data in columns 5 and 6 of Table 1 have been plotted in Figure 1 to give a "user characteristic curve." This curve is a plot of the percentage of monographs circulated versus the percentage of users accounting for the circulation.

Figure 1 shows that only 12.5 per cent of the number of active borrowers accounted for 50 per cent of the circulation. Similarly, 50 per cent of the active borrowers accounted for 90 per cent of the circulation.

The AF Cambridge research library contains approximately one hundred and twenty-five thousand volumes, primarily in the physical and environmental sciences area. It provides services to the approximately one thousand scientists, engineers, and staff members of the AF Cambridge research laboratory located at L. G. Hanscom Field in Bedford, Massachusetts. The laboratory is a part of the Air Force Office of Aerospace Research. It is interesting to note that 835 individuals out of a possible one thousand borrowed at least one monograph during the period of study.

\section{ConClusions}

The results are presented primarily for informational purposes. The salient point 
TABLE 1

AFCRL MONOGRAPHS

(Six months circulation)

\begin{tabular}{|c|c|c|c|c|c|}
\hline $\begin{array}{l}\text { NUMBER OF } \\
\text { MONOGRAPHS } \\
\text { BORROWED } \\
\text { PER USER }\end{array}$ & $\begin{array}{l}\text { CUMULATIVE } \\
\text { NUMBER OF } \\
\text { MONOGRAPHS } \\
\text { BORROWED }\end{array}$ & NUMBER OF USERS & $\begin{array}{l}\text { Cumulative } \\
\text { Number OF USERS }\end{array}$ & $\begin{array}{l}\text { Cumulative } \\
\text { Percentage of } \\
\text { Total Number of } \\
\text { Monographs } \\
\text { Circulated }\end{array}$ & $\begin{array}{l}\text { Cumulative } \\
\text { Percentage of } \\
\text { Total Number } \\
\text { OF USERS }\end{array}$ \\
\hline $\begin{array}{l}70 \text { or more } \\
60-69 \\
50-59 \\
40-49 \\
30-39 \\
20-29 \\
10-19 \\
5-9 \\
4 \\
3 \\
2 \\
1\end{array}$ & $\begin{array}{r}827 \\
1,217 \\
1,950 \\
2,882 \\
3,730 \\
5,139 \\
7,084 \\
8,167 \\
8,399 \\
8,576 \\
8,806 \\
8,966\end{array}$ & $\begin{array}{r}8 \\
6 \\
13 \\
21 \\
25 \\
60 \\
145 \\
165 \\
58 \\
59 \\
115 \\
160\end{array}$ & $\begin{array}{r}8 \\
14 \\
27 \\
48 \\
73 \\
133 \\
278 \\
443 \\
501 \\
560 \\
675 \\
835\end{array}$ & $\begin{array}{r}9.2 \\
13.6 \\
21.8 \\
32.1 \\
41.6 \\
57.4 \\
79.0 \\
91.1 \\
93.6 \\
95.5 \\
98.2 \\
100.0\end{array}$ & $\begin{array}{c}.95 \\
1.7 \\
3.2 \\
5.75 \\
8.7 \\
15.9 \\
33.3 \\
53.0 \\
60.0 \\
67.0 \\
80.3 \\
100.0\end{array}$ \\
\hline
\end{tabular}

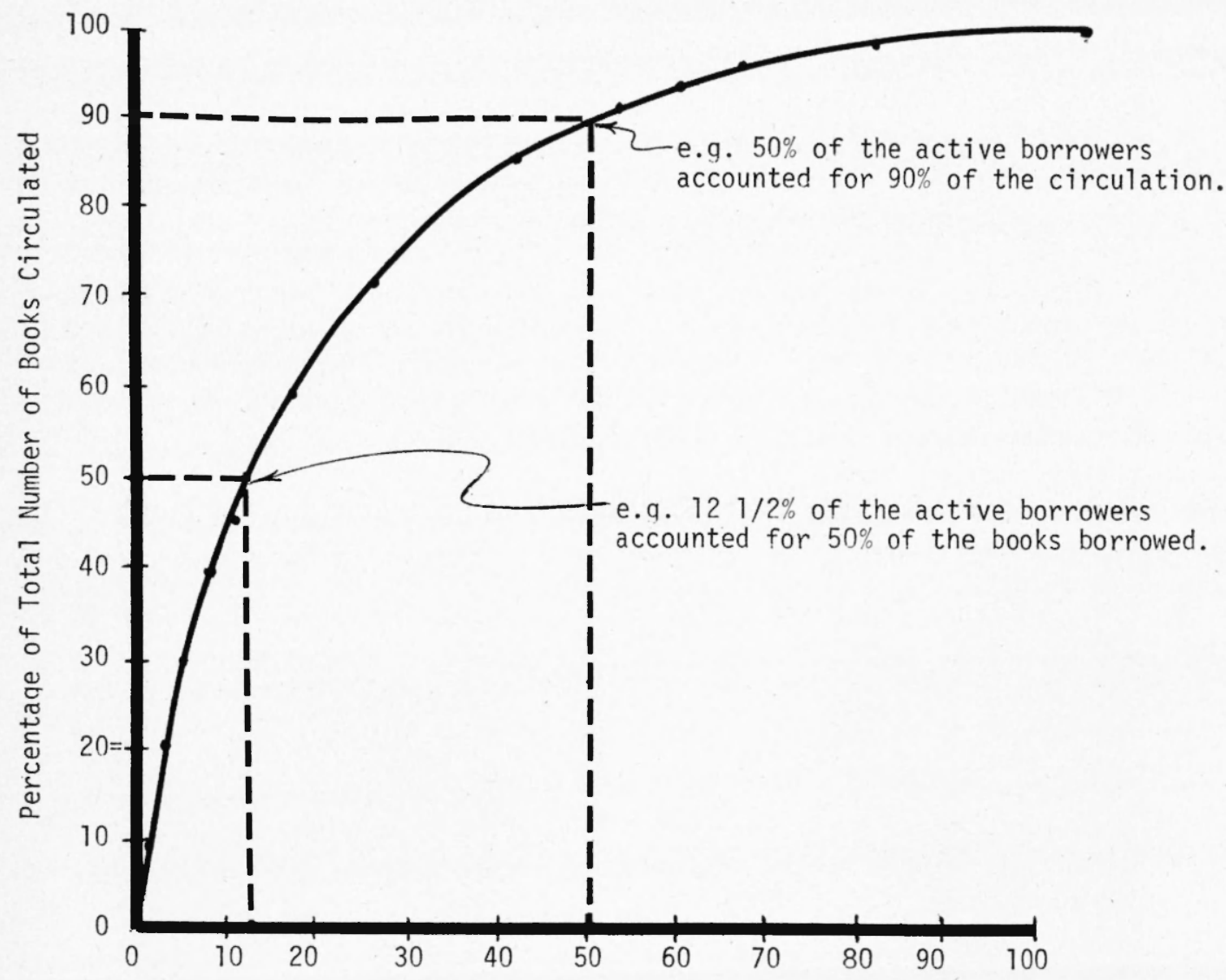

Percentage of Total Number of Active Users

FIG. 1.-User circulation curve 
of the study is the fact that a very small similar to the results from other liproportion of the active borrowers ac- braries. counted for a very large segment of the circulation. Librarians would expect a pattern something like this, but the data provide a quantitative picture. It is for a given library and may or may not be

The study also provides some quantitative data that should be useful to library researchers for library systems model building and to librarians as an aid in developing operating policy.

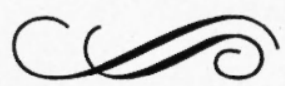

